\title{
CK2 kinase activity but not its binding to $C K 2$ promoter regions is implicated in the regulation of $C K 2 \alpha$ and $C K 2 \beta$ gene expressions
}

\author{
Sarah Lupp • Catalina Gumhold • Emmanuel Ampofo • \\ Mathias Montenarh $\cdot$ Karen Rother
}

Received: 19 March 2013/Accepted: 9 August 2013

(c) Springer Science+Business Media New York 2013

\begin{abstract}
Protein kinase CK2, a ubiquitous serine/threonine kinase in control of a variety of crucial cellular functions, is composed of catalytic $\alpha$ - and $\alpha^{\prime}$-subunits and non-catalytic $\beta$-subunits which form holoenzymes such as $\mathrm{CK} 2(\alpha \beta)_{2}, \mathrm{CK} 2 \alpha \alpha^{\prime} \beta_{2}$, or CK2 $\left(\alpha^{\prime} \beta\right)_{2}$. In addition, there is ample evidence for the occurrence of the individual subunits beside the holoenzyme. While the CK2 subunits are well analyzed on the protein level, only little is known about the regulation of their transcription. The existence of multiple forms of CK2 subunits raised the question about a mutual regulation of their expression. Here we defined two $5^{\prime}$-upstream regions of the $C K 2 \alpha$ and the $C K 2 \beta$ genes, respectively, as sequences with promoter activities. We found that CK2 $\alpha$ and $\mathrm{CK} 2 \alpha^{\prime}$ stimulated the expression of the reporter constructs whereas, CK2 $\beta$ was inactive. Using chromatin immunoprecipitation assays, we were unable to detect binding of endogenous CK2 subunits to these promoter sequences in vivo. However, it turned out that inhibition of the kinase activity of CK2 attenuated the promoter activity indicating that $\mathrm{CK} 2 \alpha$ and $\mathrm{CK} 2 \alpha^{\prime}$ might regulate their gene expression indirectly by phosphorylation reactions. Thus, we have shown here (i) that under normal physiological conditions CK2 does not bind to $C K 2$
\end{abstract}

Mathias Montenarh and Karen Rother have contributed equally to this work.

S. Lupp · C. Gumhold · E. Ampofo - M. Montenarh · K. Rother Department of Medical Biochemistry and Molecular Biology, Saarland University, 66421 Homburg, Germany

C. Gumhold · K. Rother $(\square)$

Department of Medical Biochemistry and Molecular Biology,

Center of Human and Molecular Biology, Saarland University,

Building 44, 66421 Homburg, Germany

e-mail: karen.rother@uks.eu promoter regions and (ii) that the CK2 kinase activity is implicated in the regulation of its own expression.

Keywords Protein kinase CK2 - Gene expression . Transcriptional regulation $\cdot$ DNA binding

\section{Introduction}

Protein kinase CK2, formerly known as casein kinase 2, is known for more than 50 years [1]. It is a ubiquitously expressed protein kinase which phosphorylates more than 500 different substrates and this number is steadily increasing. This large number of different substrates indicates that CK2 is implicated in numerous cellular processes including regulation of cell proliferation and survival [2, 3]. An elevated expression level and an increased kinase activity for CK2 were found in tumor cells compared to normal, non-transformed cells [4]. This later observation made CK2 an interesting pharmacological target for the treatment of cancer $[5,6]$.

Thornburg and Lindell [7] first described CK2 as a multi-subunit protein kinase that is generated by the association of two $\alpha$-and/or $\alpha^{\prime}$-subunits with a dimer of the $\beta$-subunit. This structure and composition of CK2 was quickly confirmed by Dahmus and Natzle [8]. Stigare, however reported in 1993, that CK2 $\alpha$ was tightly bound to nuclear structures in the absence of its $\beta$-subunit [9] indicating that the CK2 subunits exist not only in the holoenzyme but also in a free form or individually associated with other cellular proteins or structures. An unbalanced expression of $\mathrm{CK} 2 \alpha$ and $\mathrm{CK} 2 \beta$ subunits was later on described for different mammalian tissues [10-12]. CK2 $\alpha$ is not only active as a phosphotransferase in the holoenzyme but also in the absence of CK2 $\beta$. Loss of CK2 $\beta$ is 
lethal [13] which may imply that some aspects of the CK2 $\beta$ functions are not based on its interaction with the CK2 $\alpha$ subunits. Live cell fluorescence imaging revealed that CK $2 \alpha$ and CK2 $\beta$ show an independent movement within a eukaryotic cell. Furthermore, CK2 $\alpha$ and CK2 $\beta$ enter the nucleus independently [14]. Unlike CK2 $\beta$, nuclear CK2 $\alpha$ can be exported back to the cytosol. Finally, a large excess of CK2 $\beta$ is synthesized compared to CK2 $\alpha$ and the noncomplexed CK2 $\beta$ protein is rapidly degraded [15]. The human genome contains two $C K 2 \alpha$ loci, at chromosomes $20 \mathrm{p} 13$ and $11 \mathrm{p} 15$, where primarily the locus on chromosome 20 is transcriptionally active. The locus on chromosome 11 was thought to be a permanently silent pseudogene [16-19]. However, it turned out that this intronless $C K 2 \alpha$ gene is expressed in some cancer cells but only minimally expressed in normal cells [20]. It therefore still has to be clarified whether or not it is a protein-coding gene or a processed pseudogene.

The $C K 2 \alpha^{\prime}$ gene has been mapped to chromosome 16p13.2-13.3 [21], whereas the $C K 2 \beta$ gene has been mapped to chromosome $6 \mathrm{p} 21.3$ [17]. The genomic structures of the different $C K 2$ genes in various organisms have been characterized [22-28]. Due to the fact that the individual CK2 subunits assemble into the holoenzyme, which is composed of two CK $2 \alpha$ or CK $2 \alpha^{\prime}$ and two CK2 $\beta$ subunits and that the subunits exist outside of the holoenzyme, it was an obvious question whether the expression of the subunits might be coordinately regulated. The promoter regions for the different $C K 2$ genes were characterized and furthermore it was shown, that $\mathrm{CK} 2 \alpha$ appears to function as a trans-activating factor for the $C K 2 \beta$ gene transcription [29]. Electrophoretic Mobility Shift Assays (EMSA) suggested a binding of CK2 $\alpha$ to the $C K 2 \beta$ promoter. Overexpression of CK2 $\alpha$ resulted in an elevated level of CK2 $\beta$ protein which might suggest that $\mathrm{CK} 2 \alpha$ stimulate the transcription of $C K 2 \beta$ although other mechanisms are possible. Previously, it has been shown that CK2 activity is down-regulated at the transcriptional level in both senescent lung fibroblasts and in aged rat tissues and it has been proposed that DNA methylation may be involved in inactivating CK2 in senescent cells [30]. Possibly, promoter methylation may be used as a general mechanism for regulation of CK2 expression. However, so far there is no indication for direct methylation of the $C K 2 \alpha$ and $C K 2 \beta$ promoters [31].

While the cellular stoichiometry of the catalytic and the regulatory subunits are well characterized, the situation at the transcriptional level is less clear. Thus, we decided to analyze the influence of CK $2 \alpha, \mathrm{CK} 2 \alpha^{\prime}$, and CK2 $\beta$ on the $C K 2 \alpha$ and $C K 2 \beta$ promoters. In contrast to previous studies, we used DNA sequences of at least $1.3 \mathrm{~kb}$ directly upstream of the translational start sites instead of small DNA fragments. We found that the CK2 catalytic subunits stimulated the expression of both, the $C K 2 \alpha$ and $C K 2 \beta$ genes. However, using chromatin immunoprecipitation assays, we found no direct binding of CK2 $\alpha$ and CK2 $\beta$ to these promoter DNAs. Instead, transcription was attenuated after inhibition of the CK2 kinase activity by two different CK2 inhibitors indicating that the enzyme activity is necessary for transcriptional regulation of the CK2 subunits.

\section{Materials and methods}

Cell culture and drug treatment

HCT116 cells are human colon carcinoma cells, which were previously characterized in detail [32] and were a kind gift from Vogelstein [33]. Cells were cultured in McCoy's 5A Modified Medium with GlutaMAX ${ }^{\mathrm{TM}}$-I (Life Technologies, Darmstadt, Germany) containing $10 \%$ fetal calf serum (FCS; PAA, Pasching, Austria) at $37^{\circ} \mathrm{C}$ and $5 \% \mathrm{CO}_{2}$ in a humidified atmosphere. For selective inhibition of endogenous CK2 kinase activity, HCT116 cells were treated with CK2 inhibitors CX-4945 ( 1 or $10 \mu \mathrm{M}$ in DMSO, Selleckchem, München, Germany) or TF (50 $\mu \mathrm{M}$ in DMSO, a kind gift from Joachim José [34]) for $24 \mathrm{~h}$ or with DMSO as solvent control.

\section{CK2 protein kinase assay}

To study CK2 kinase activity in cell extracts, $30 \mu \mathrm{g}$ of total protein was mixed with $20 \mu$ lof kinase buffer [ $50 \mathrm{mM}$ Tris$\mathrm{HCl}, \mathrm{pH} 7.5,100 \mathrm{mM} \mathrm{NaCl}, 10 \mathrm{mM} \mathrm{MgCl} 2,1 \mathrm{mM}$ dithiothreitol (DTT)]. After addition of $30 \mu \mathrm{l}$ of CK2 assay mix (25 mM Tris- $\mathrm{HCl}, \mathrm{pH} 8.5,150 \mathrm{mM} \mathrm{NaCl}, 5 \mathrm{mM} \mathrm{MgCl}_{2}$, $1 \mathrm{mM}$ DTT, $50 \mu \mathrm{M}$ ATP, 0.19 mM CK2-specific substrate peptide with the sequence RRRDDDSDDD, $10 \mu \mathrm{Ci}$ $\left.(0.37 \mathrm{MBq})\left[\gamma-{ }^{32} \mathrm{P}\right] \mathrm{ATP}\right)$, the reaction mix was incubated at $37{ }^{\circ} \mathrm{C}$ for $5 \mathrm{~min}$ and then stopped on ice. The sample was pipetted onto Whatman-P81 cation-exchange paper and washed three times with $85 \mathrm{mM}$ phosphoric acid for $5 \mathrm{~min}$, followed by washing with ethanol. The dried filter paper was counted for Čerenkov radiation in a scintillation counter (Liquid Scintillation Analyzer 190S AB/LA; CanberraPackard GmbH, Dreieich, Germany).

Plasmids and cloning of promoter constructs

Firefly luciferase reporter vector (pGL4.10) and Renilla luciferase reporter control vector (pGL4.70) were from Promega (Mannheim, Germany). The human $C K 2 \alpha(P I)$ promoter fragment, containing 1329 nucleotides upstream of the start codon, was obtained by PCR amplification with the primers CK2 $\alpha$-hum-prom-ATG-1329-for: $5^{\prime}$-ATG AAG CTT GTG CGG TGG CTC ACA TCT GTG-3'; 
CK2 $\alpha$-hum-prom-ATG-rev: 5 -ATG CCA TGG GCA TGT CAG ACA GGT TGG CGG AC- $3^{\prime}$ and cloned (HindIII/ NcoI) into pGL4.10. The human CK2 $\alpha$ (PII) promoter fragment, containing 1920 nucleotides upstream of the first exon, was obtained by PCR amplification with the primers CK2 $\alpha$-hum-prom-up-for: $5^{\prime}$-ATG AGA TCT AGG TAA GCT CCA CCA GTG AGC-3'; CK2 $2 \alpha$-hum-prom-up-rev: $5^{\prime}$-ATG AAG CTT GCT CTC CCC TCT GCT CAC AC-3' and cloned (BglII/HindIII) into pGL4.10. The human $C K 2 \beta$ promoter fragment, containing 1896 nucleotides upstream of the start codon, was obtained by PCR amplification with the primers CK2 $\beta$-hum-prom-for: 5'-AGA AGA TCT CGG GGA GAG TCT C- ${ }^{\prime}$; CK2 $\beta$-hum-prom-rev: $5^{\prime}$-ATG CCA TGG AGC TGC TCA TCT TCA CGT CAG- ${ }^{\prime}$ and cloned $(B g l \mathrm{II} / \mathrm{NcoI})$ into pGL4.10. All sequences of cloned fragments were confirmed by DNA sequencing.

The p3xFLAG-CMV-7.1-basic vector was from SigmaAldrich (München, Germany). To generate the expression plasmids p3xFLAG-CMV-7.1-CK2 $\alpha$ and p3xFLAG-CMV7.1-CK2 $\alpha^{\prime}$, the human cDNA of CK2 $\alpha$ (1176 nucleotides) and CK2 $\alpha^{\prime}$ (1050 nucleotides) were cloned into p3xFLAGCMV-7.1-basic with HindIII and BamHI. The sequences of both DNA constructs were verified by sequencing. The expression plasmids of the kinase-dead mutants CK2 $\alpha$ mut $(\mathrm{K} 68 \mathrm{M})$ and $\mathrm{CK} 2 \alpha^{\prime}$ mut $(\mathrm{K} 69 \mathrm{M})$ were a generous gift from Litchfield [35]. Both cDNAs were subcloned in p3xFLAGCMV-7.1-basic vector as described earlier [36]. The probasin promoter construct was a kind gift from Thomas Kietzmann and Elitsa Dimova.

Transient transfection, cell lysis, and luciferase assay

Transfection of cells was performed by using the Turbofect ${ }^{\circledR}$ Transfection Reagent (Thermo Scientific, St. Leon-Rot, Germany) according to the manufacturer's instructions.

For the luciferase reporter assay, HCT116 cells were seeded into a 24 -well plate $(40,000$ cells per well) in a total volume of $0.5 \mathrm{ml} /$ well of cell culture medium and cultured overnight. Cells were then transfected using a total of $1 \mu \mathrm{g}$ of plasmid DNA by using Turbofect ${ }^{\mathbb{B}}$ transfection reagent (transfection mixture per well: $0.3 \mu \mathrm{g}$ of promoter reporter plasmid, $0.2 \mu \mathrm{g}$ of Renilla luciferase control plasmid, $0.5 \mu \mathrm{g}$ of indicated expression plasmid, $2 \mu$ l Turbofect ${ }^{\circledR}$ transfection reagent and $200 \mu \mathrm{l}$ cell culture medium without FCS).

For western blot analysis, HCT116 cells were seeded into a 6-well plate $(800,000$ cells per well) in a total volume of $2 \mathrm{ml} /$ well of cell culture medium. Cells were cultured overnight and were then transfected using Turbofect ${ }^{\circledR}$ transfection reagent using a total of $4 \mu \mathrm{g}$ of plasmid DNA (transfection mixture per well: $1 \mu \mathrm{g}$ of promoter reporter plasmid, $1 \mu \mathrm{g}$ of Renilla luciferase control plasmid, $2 \mu \mathrm{g}$ of indicated expression plasmid, $6 \mu \mathrm{l}$ of Turbofect ${ }^{\circledR}$ transfection reagent and $400 \mu \mathrm{l}$ of cell culture medium without FCS).
For measuring luciferase activity, cells were collected at given time points after transfection by lysing in passive lysis buffer (PLB, Promega) and measured with the DualLuciferase Reporter Assay System (Promega) following the manufacturer's recommendations. Relative light units (RLUs) were calculated by normalizing firefly luciferase activity to Renilla luciferase activity.

For western blot analysis, cell lysates were centrifuged at $13,000 \times g$ to remove cell debris. The protein content was determined with the Roti ${ }^{\circledR}$-Quant kit (Roth, Karlsruhe, Germany). Protein extracts were immediately used for western blot analysis or stored at $-20{ }^{\circ} \mathrm{C}$.

SDS-polyacrylamide gel electrophoresis and western blot analysis

Proteins were analyzed by SDS-polyacrylamide gel electrophoresis following standard protocols [37]. In brief, $50 \mu \mathrm{g}$ of proteins per lane were dissolved in sample buffer $(130 \mathrm{mM}$ Tris-HCl, pH 6.8, $0.02 \%$ bromophenol blue (w/v), $10 \%$ $\beta$-mercaptoethanol, $20 \%$ glycerol (v/v), and $4 \% \operatorname{SDS}(\mathrm{w} / \mathrm{v}))$ and separated on a $12.5 \%$ SDS-polyacrylamide gel in electrophoresis buffer (25 mM Tris-HCl, pH 8.8, $192 \mathrm{mM}$ glycine, and $3.5 \mathrm{mM} \mathrm{SDS}$ ) and transferred onto a PVDF membrane (Roche Diagnostics, Mannheim, Germany) in a buffer containing $20 \mathrm{mM}$ Tris- $\mathrm{HCl}, 150 \mathrm{mM}$ glycine, $\mathrm{pH}$ 8.3. The membrane was blocked with $5 \%$ dry milk in PBS with $0.1 \%$ of Tween20 (PBST) for $1 \mathrm{~h}$ and then incubated with appropriate primary antibodies diluted in PBST with $1 \%$ dry milk (incubation buffer). For the detection of protein kinase CK2, we used rabbit anti-peptide serum \#26 ( $\alpha$-subunit) [38], rabbit polyclonal anti-CK2 $\beta$ serum and the monoclonal antibody anti-FLAGM2 (F3165, SigmaAldrich). We used an $\alpha$-tubulin-specific mouse monoclonal antibody (clone DM1A, Sigma-Aldrich) as loading control. All the antibodies were diluted 1:1,000 in incubation buffer and incubated with the membrane for $1 \mathrm{~h}$ at room temperature or overnight at $4{ }^{\circ} \mathrm{C}$. The membrane was washed twice with incubation buffer and incubated with a horseradish peroxidase (HRP)-conjugated secondary antibody (goat anti-rabbit $\operatorname{IgG}, 1: 30,000$ or goat anti-mouse $\operatorname{IgG} 1: 30,000$ in incubation buffer; Santa Cruz Biotechnology, Santa Cruz, CA, USA) for $1 \mathrm{~h}$ at room temperature. Chemiluminescence signals were visualized by the ECL Lumilight system of Roche Diagnostics according to the manufacturer's instructions.

\section{Chromatin immunoprecipitations (ChIP)}

ChIP assays were performed with minor modifications as described earlier [39]. $1 \%$ of crosslinked and sonicated chromatin of HCT116 cells was taken as input and kept at $4{ }^{\circ} \mathrm{C}$ overnight instead of precipitation. DNA from approximately $2.5 \times 10^{6}$ cells was used in each immunoprecipitation 
with the following antibodies: anti-CK2 $\alpha$, rabbit anti-peptide serum \#26 [38]; anti-CK2 $\beta$, rabbit polyclonal antibody against full length protein; anti-SP1 rabbit polyclonal antibody (07-645, Merck Millipore, Darmstadt, Germany); normal rabbit IgG (sc-2027, Santa Cruz Biotechnology), used as a control for non-specific signals. For the precipitations, $1 \mu \mathrm{g}$ of normal rabbit IgG, $4 \mu \mathrm{g}$ of antibody anti-SP1, and $20 \mu \mathrm{l}$ of anti-peptide sera were utilized. After addition of the antibodies, the samples were incubated at $4{ }^{\circ} \mathrm{C}$ overnight on a rotating wheel. Twenty-five microlitre of Protein G Dynabead suspension (Life Technologies) were used to purify antibodybound protein-DNA complexes. The beads were washed seven times with wash buffer $(0.25 \mathrm{M} \mathrm{LiCl}, 0.5 \%(\mathrm{v} / \mathrm{v})$ Nonidet P-40, $0.5 \%$ (w/v) sodium deoxycholate, $1 \mathrm{mM}$ EDTA, $10 \mathrm{mM}$ Tris-HCl, $\mathrm{pH}$ 8.0) before the bound complexes were eluted twice, each with $100 \mu$ l elution buffer (50 mM Tris-HCl, pH 8.0, $0.1 \%$ (w/v) SDS, $10 \mathrm{mM}$ EDTA) at $28^{\circ} \mathrm{C}$. After elution, formaldehyde crosslinks were reversed and DNA was precipitated and purified. qPCR was then carried out using the Brilliant III Ultra-Fast SYBR ${ }^{\circledR}$ Green QPCR Master Mix kit (Agilent Technologies, Böblingen, Germany) with the following primers (Fig. 1a, b): ChIP-CK2 $\alpha$ hum for: $5^{\prime}$-GGG AGG TTC GTG TTC TCT CT-3', ChIP-CK2 $\alpha$ hum rev: 5'-GGA ATC TCT CTG AAT GCG GC-3'; ChIP-CK $2 \beta$ hum for: $5^{\prime}$-CCA TAA GGA CCC AGC GGA TTG-3', ChIP-CK2 $\beta$ hum rev: 5'-CAA CGA GAA GCC ACC GGA AG-3', ChIP-GAPDHS hum for: 5'-AGA CCA GCC TGA GCA AAA GA-3', ChIP-GAPDHS hum rev: 5'-CTA GGC TGG AGT GCA GTG GT-3'. Product amplification was carried out with an annealing temperature of $62{ }^{\circ} \mathrm{C}$ for 40 cycles using $1 \mu \mathrm{l}$ of DNA solution as template in the PCR Reader Mx3000Pro ${ }^{\mathrm{TM}}$ (Agilent Technologies). All PCR results were normalized to input controls.

\section{Statistical analysis}

Results of luciferase reporter assays in Fig. 2a, d were expressed as mean \pm standard deviation (SD) of at least eight independent experiments. Statistical analysis of the data was performed using the Two-sample $t$-test (Origin software; OriginLab Corporation, Northampton, MA, USA). $p<0.05$ was considered significant.

\section{Results}

The relevant promoter regions of CK2 subunit genes reside upstream of their respective transcriptional start sites

For the analysis of transcriptional regulation of CK2 subunit expression, relevant promoter regions have to be identified. Especially the organization of the $C K 2 \alpha$ gene with the first untranslated exon located over $35 \mathrm{~kb}$ upstream of its translational start site emerges the question, which DNA region harbors the relevant promoter region of this gene. Therefore, in contrast to previous studies [29], we amplified extended DNA regions of over $1.3 \mathrm{~kb}$ directly upstream of the $C K 2 \alpha$ start codon (PI, Fig. 1a) as well as nearly $2 \mathrm{~kb}$ immediately upstream of the distant transcriptional start sites of the $C K 2 \alpha$ gene (PII, Fig. 1a) by PCR and cloned both potential $C K 2 \alpha$ promoter fragments into luciferase reporter vector pGL4.10. For analysis of the transcriptional regulation of the $C K 2 \beta$ gene, we amplified and cloned a DNA fragment encompassing $1.9 \mathrm{~kb}$ upstream of the $C K 2 \beta$ start codon, including the transcriptional start site, the first untranslated exon 1 as well as intron 2 of the $C K 2 \beta$ gene (Fig. 1b).

HCT116 cells were transfected with the reporter constructs together with a Renilla luciferase plasmid to calculate the transfection efficiency. As a further control, we also transfected the vector DNA without the putative promoter regions into HCT116 cells. Cells were extracted and the luciferase activity was measured as described in "Materials and methods" section. The luciferase reporter gene assays reveal clearly that only those DNA sequences directly upstream of the transcriptional start site of $C K 2 \alpha$ and $C K 2 \beta$ genes, $P I I$ and $C K 2 \beta$, exhibit very strong promoter activities (Fig. 1c). The sequence immediately upstream of the translational start site $(P I)$ showed no promoter activity. Therefore, no further experiments were carried out with this inactive reporter construct. For simplicity, the active promoter construct $C K 2 \alpha(P I I)$ is hereinafter called $C K 2 \alpha$ promoter. In the next step, we analyzed whether the reporter assay is dose dependent. Therefore, 50,100 , or $300 \mathrm{ng}$ of the promoter constructs were transfected into HCT116 cells. The following reporter assay revealed that the luciferase activity increased with increasing concentrations of the reporter constructs (Fig. 1d). The relative luciferase light units were displayed relative to the vector control.

Ectopic expression of catalytic CK2 subunits but not of their kinase-dead mutants leads to a modest but significant increase in promoter activity of $C K 2 \alpha$ and $C K 2 \beta$ promoters

Regulation of $C K 2 \alpha$ and $C K 2 \beta$ gene expressions at the transcriptional level is not well characterized to date. More than 20 years ago CK $2 \alpha$ was found to bind to calf thymus DNA and to $\lambda$-phage DNA [40]. Later on, the CK2 $\alpha$ protein was found to complex with the $C K 2 \beta$ gene promoter [29]. Therefore, we decided to analyze whether the catalytic subunits of CK2 (CK2 $\alpha$ or CK $\left.2 \alpha^{\prime}\right)$ might influence the expression of CK2 subunits. To this end, we transiently transfected cells with an active reporter construct 

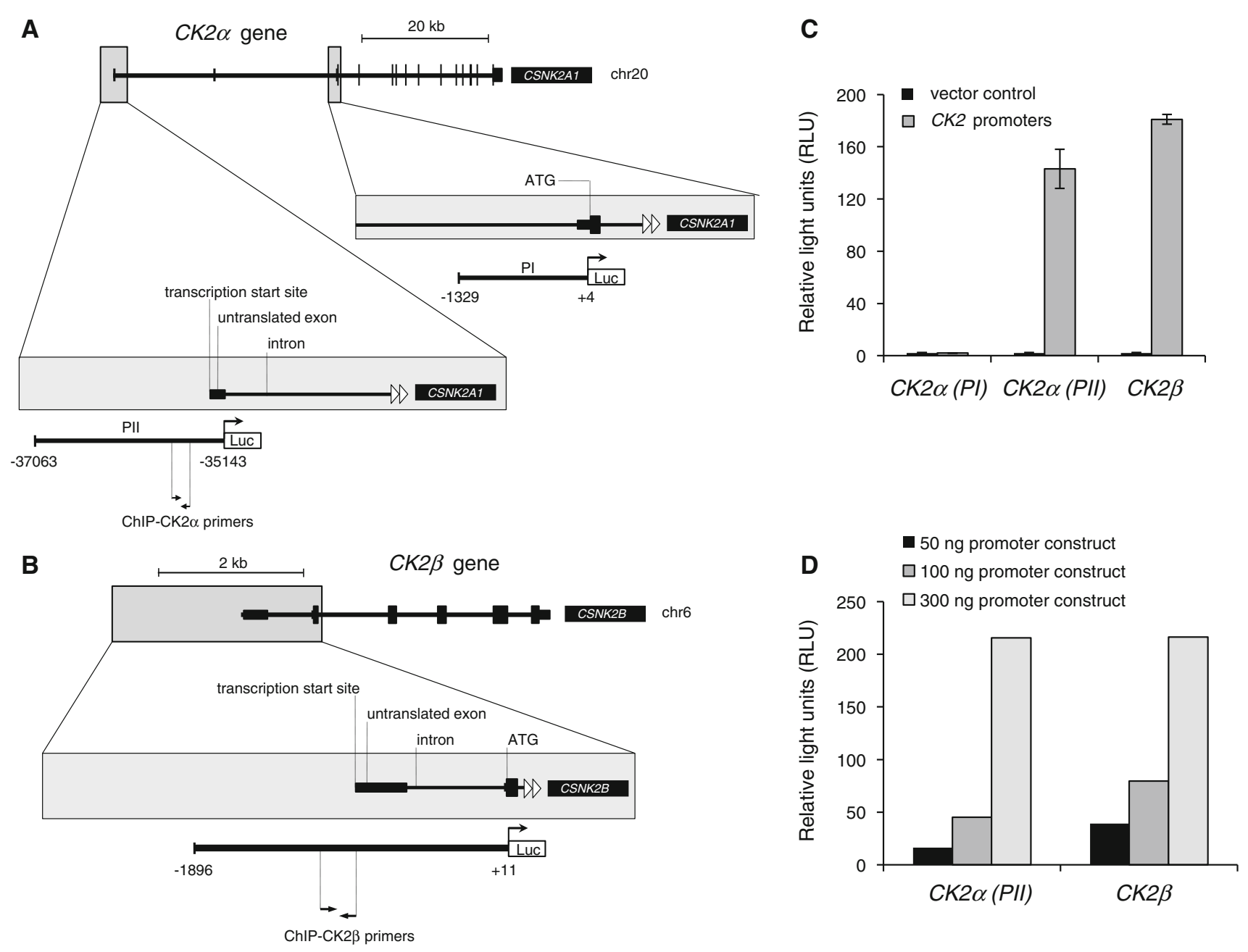

Fig. 1 Genomic architecture of $C K 2$ genes and identification of relevant promoter regions. Positions of transcription start sites, exons, introns, start ATGs, and primers used for ChIP analyses (Fig. 4) are shown. a Potential promoter regions (PI and PII) of $C K 2 \alpha$ gene are enlarged and cloned DNA-fragments are depicted by black bars in front of the coding sequence of the firefly luciferase gene (Luc). Nucleotide positions relative to the original translational start site of $C K 2 \alpha$ gene are indicated. b The potential promoter region of the $C K 2 \beta$ gene is enlarged and the cloned DNA-fragment is depicted by a

(CK2 $\alpha$-luc and CK2 $\beta$-luc, respectively), together with plasmids coding for $\mathrm{CK} 2 \alpha, \mathrm{CK} 2 \alpha^{\prime}$ or an empty vector control. Our data clearly demonstrated a modest but significant increase in $C K 2 \alpha$ as well as $C K 2 \beta$ promoter activities after ectopic expression of CK2 $\alpha$ (Fig. 2a) and CK2 $\alpha^{\prime}$ subunits (Fig. 2d). These trans-activating effects observed $24 \mathrm{~h}$ after transfection increased further when incubation time was extended to $48 \mathrm{~h}$. No further increase was observed $72 \mathrm{~h}$ after transfection (Fig. 2a, d). Western blot analysis with aliquots of transfected cells demonstrated protein expression of FLAG-tagged CK2 $\alpha$ and $\mathrm{CK} 2 \alpha^{\prime}$ subunits, respectively (Fig. 2a, d) demonstrating that similar amounts of CK2 $\alpha$ or CK $2 \alpha^{\prime}$ were used for the determination of the luciferase activity. In contrast, ectopic black bar in front of the coding sequence of the firefly luciferase gene (Luc). Nucleotide positions relative to the original translational start site of the $C K 2 \beta$ gene are indicated. $\mathbf{c}, \mathbf{d}$ Dual luciferase reporter gene assays were carried out in HCT116 cells after transient transfection of $250 \mathrm{ng}$ or indicated amount of different $C K 2$ promoter constructs. c Empty firefly luciferase reporter vector (pGL4.10) served as vector control. Relative luciferase light units (RLU) were displayed relative to the vector control. Mean $\pm \mathrm{SD}, n=3$. d Relative luciferase light units (RLU) of one representative experiment are shown

expression of kinase-inactive mutants of $\mathrm{CK} 2 \alpha(\mathrm{K} 68 \mathrm{M})$ or $\mathrm{CK} 2 \alpha^{\prime}(\mathrm{K} 69 \mathrm{M})$ [35] significantly influenced neither $C K 2 \alpha$ nor $C K 2 \beta$ promoter activities (Fig. 2c, f), although cotransfection of expression plasmids for these mutants lead to a clear increase in the respective protein level (Fig. 2c, f). As a further control, we analyzed effects of ectopic expression of FLAG-tagged CK $2 \alpha$ and CK2 $\alpha^{\prime}$ subunits towards (i) the probasin promoter and (ii) the empty reporter plasmid pGL4.10. We found that expression of CK $2 \alpha$ or CK $2 \alpha^{\prime}$ had no influence, neither on the empty reporter plasmid (pGL4.10) nor on the probasin promoter (Fig. 2b, e).

As CK2 $\alpha$ and CK2 $\beta$ form heterotetramers, we additionally analyzed promoter activities after co-expression of both 
A
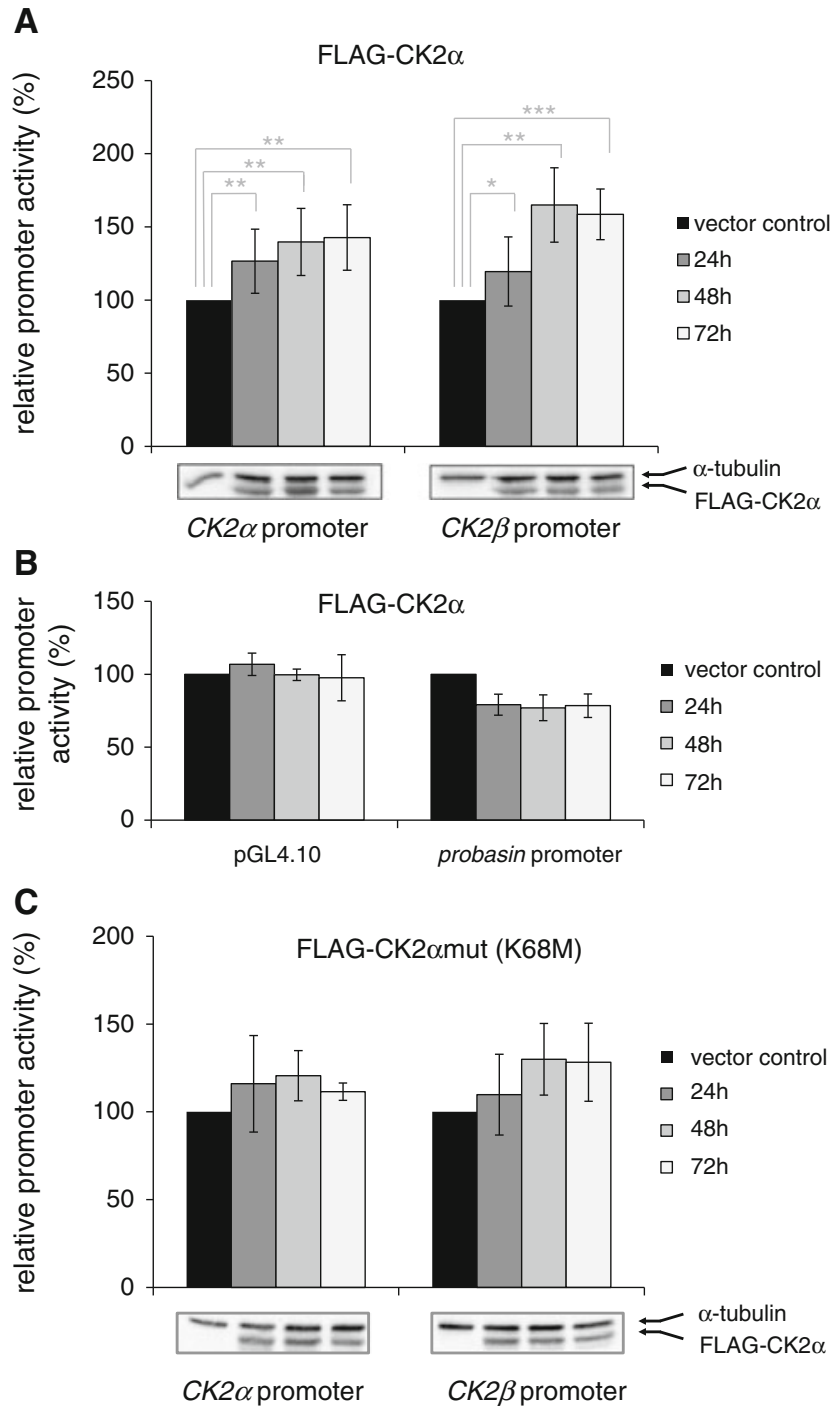

Fig. 2 Ectopic expression of catalytic subunits of CK2 significantly increases promoter activities of $C K 2 \alpha$ and $C K 2 \beta$ promoters. Dual luciferase reporter gene assays were carried out in HCT116 cells after transient cotransfection of expression plasmids of wild-type CK2 $\alpha$ (a) or CK2 $2 \alpha^{\prime}$ (d) or kinase-dead mutants of CK2 $2 \alpha$ (c) or CK $2 \alpha^{\prime}$ (f) together with indicated $C K 2$ promoter constructs or an irrelevant promoter construct (probasin promoter construct) or empty reporter plasmid (pGL4.10) as negative controls (b, e). The empty expression plasmid p3xFLAG-CMV-7.1 served as vector control in each case. Relative promoter activities measured 24,48 , or $72 \mathrm{~h}$ after transient transfection, are presented here. $C K 2$ promoter activities measured

$\mathrm{CK} 2 \alpha / \mathrm{CK} 2 \alpha^{\prime}$ and CK2 $\beta$ subunits, alone and in combination. As expected, ectopic expression of CK2 $\beta$ alone did not change CK2 promoter activities significantly (Fig. 3a), whereas $\mathrm{CK} 2 \alpha$ and $\mathrm{CK} 2 \alpha^{\prime}$ led to a moderate but significant increase of both promoter activities (Fig. 3b, c). Surprisingly, neither $C K 2 \alpha$ nor $C K 2 \beta$ promoter activities increased further after combined overexpression of CK2 $\alpha$ and CK2 $\beta$ subunits
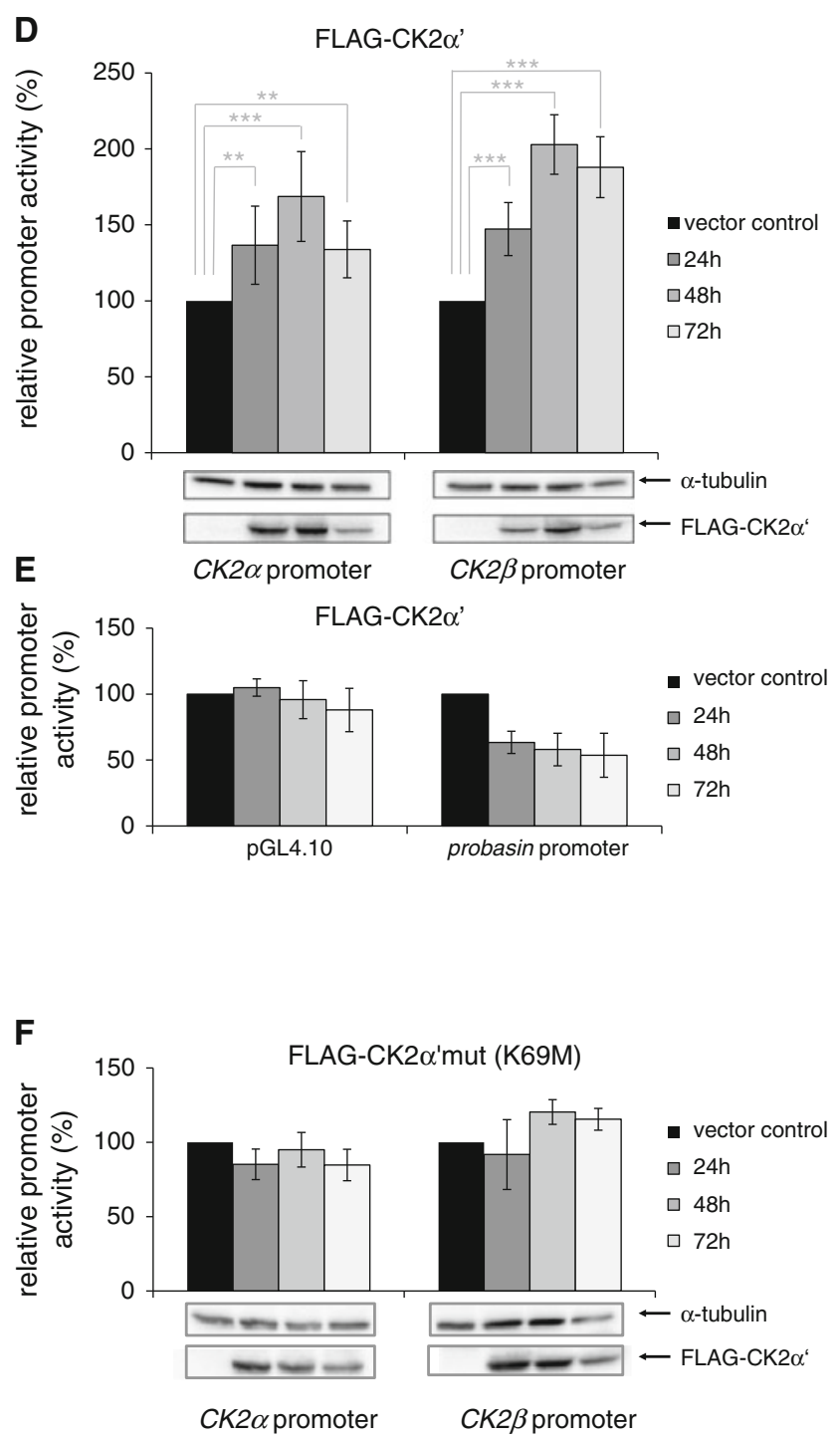

after cotransfection with the vector control were set to $100 \%$. Means and standard deviations of eight independent experiments are shown. $* p<0.05 ; * * p<0.01 ; * * * p<0.001$. Western blot analyses of cotransfected HCT116 cells were analyzed in parallel and illustrate expression of FLAG-tagged wild-type CK2 $\alpha$ (a), FLAG-tagged CK2 $\alpha$ mut (c), FLAG-tagged wild-type CK2 $\alpha^{\prime}$ (d), or FLAG-tagged CK2 $\alpha^{\prime}$ mut (f). Anti-FLAG antibody was used at a dilution of 1:1,000. Detection of $\alpha$-tubulin protein by anti- $\alpha$-tubulin antibody, at a dilution of 1:1,000, was used as a loading control for the extracts in the experiments

(Fig. 3b). Also combined expression of $\mathrm{CK} 2 \alpha^{\prime}$ and CK2 $\beta$ subunits, did not significantly change $C K 2 \alpha$ promoter activity (Fig. 3c). Solely, the activity of the $C K 2 \beta$ promoter seemed to be slightly increased after combined CK2 $\alpha^{\prime}$ and CK2 $\beta$ expression. Taken together, these data indicate that obviously monomeric CK2 rather than the holoenzyme is responsible for the observed autoregulation of CK2 expression. 


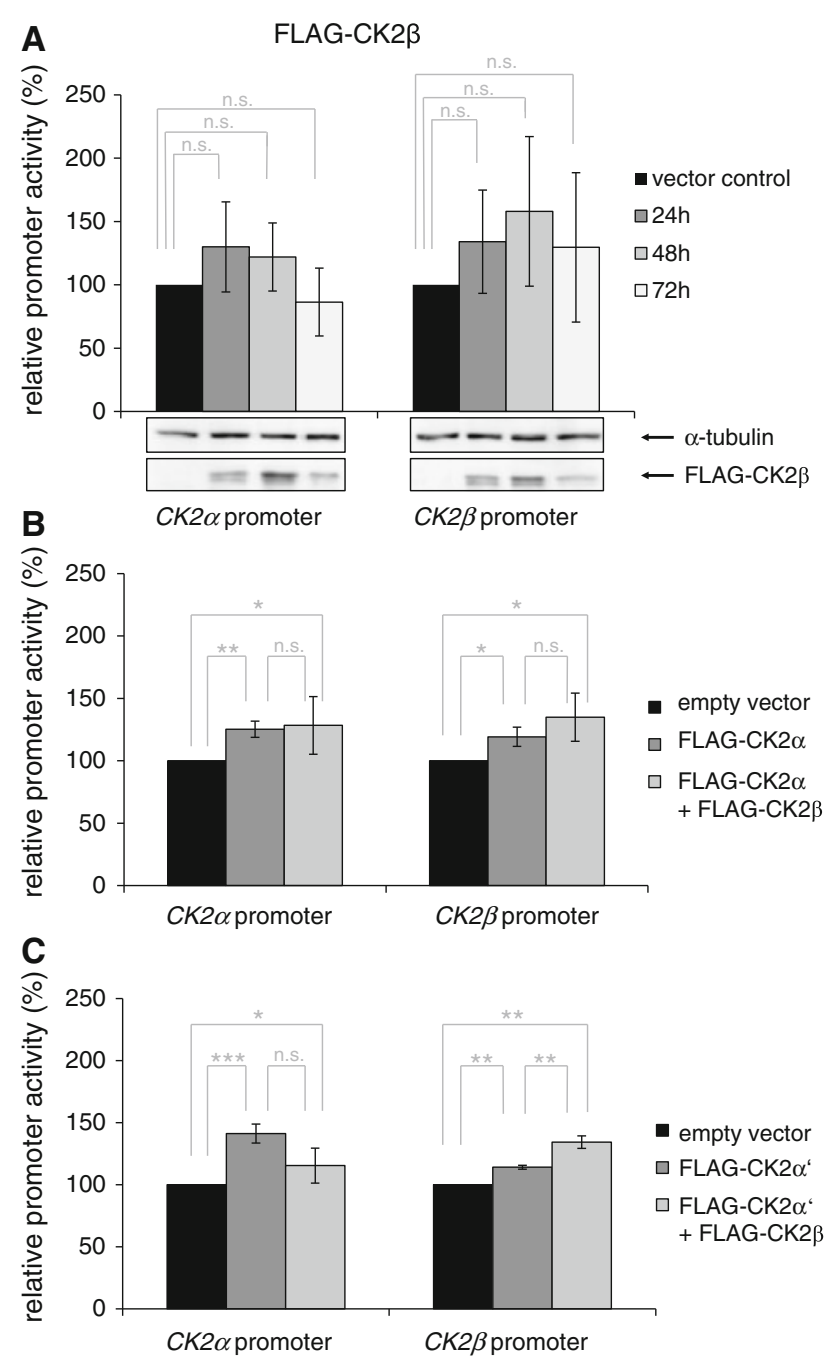

Fig. 3 Ectopic expression of non-catalytic subunit of CK2 did not significantly change promoter activities of $C K 2 \alpha$ and $C K 2 \beta$ promoters. Dual luciferase reporter gene assays were carried out in HCT116 cells after transient cotransfection of wild-type CK2 $\beta$ alone (a), CK2 $\alpha$ together with CK2 $\beta$ (b), or CK2 $\alpha^{\prime}$ together with CK2 $\beta$ (c) expression plasmids together with indicated $C K 2$ promoter constructs. The empty expression plasmid p3xFLAG-CMV-7.1 served as vector control in each case. Relative promoter activities measured 24, 48, and $72 \mathrm{~h}$ (a) or only $24 \mathrm{~h}(\mathbf{b}, \mathbf{c})$ after transient transfection, are shown. CK2 promoter activities measured after cotransfection with the vector control were set to $100 \%$. Means and standard deviations of three independent experiments are shown. $* p<0.05, \quad * * p<0.01$, $* * * p<0.001$. Western blot analyses of cotransfected HCT116 cells were analyzed in parallel and illustrate clear overexpression of FLAG-tagged wild-type CK2 $\beta$ (a). Anti-FLAG antibody was used at a dilution of $1: 1,000$. Detection of $\alpha$-tubulin protein by anti- $\alpha$-tubulin antibody, at a dilution of 1:1,000, was used as a loading control for the extracts in the experiments

Transcriptional regulation of CK2 subunits expression through CK2 $\alpha$ and CK2 $\beta$ is not dependent on their direct binding to promoter DNA

As expression of the CK2 $\alpha$ subunit leads to an increase in promoter activities of their respective genes, we wondered whether the CK2 $\alpha$ subunit might influence $C K 2 \alpha$ and $C K 2 \beta$ transcription through direct binding to their promoter regions. To analyze direct binding of CK2 subunits to the respective $C K 2$ promoter regions in vivo, we performed chromatin immunoprecipitation (ChIP) experiments. It was previously shown that the general transcription factor SP1 binds to a minimal fragment of the $C K 2 \alpha$ promoter [41] as well as to the $C K 2 \beta$ promoter [42]. Therefore, serving as a positive control in our ChIP assay, endogenous SP1 was found to bind to $C K 2 \alpha$ as well as $C K 2 \beta$ promoter regions in vivo (Fig. 4). In contrast to SP1, neither endogenous CK2 $\alpha$ nor CK2 $\beta$ were able to bind $C K 2 \alpha$ or $C K 2 \beta$ promoter DNA in vivo (Fig. 4). As a negative control, none of these proteins bind to the testisspecific glyceraldehyde-3-phosphate dehydrogenase promoter $(G A P D H S)$, indicating specific binding in the ChIP assays.

Promoter activities of $C K 2 \alpha$ and $C K 2 \beta$ decrease after inhibition of CK2 kinase activity

After exclusion of a direct binding of CK2 subunits to their respective promoter regions, we next asked whether the CK2 kinase activity might have an influence on the transcriptional regulation of $C K 2 \alpha$ and/or $C K 2 \beta$. To address this question, we transfected HCT116 cells with $C K 2 \alpha$ and $C K 2 \beta$ promoter constructs, subsequently, we blocked endogenous CK2 kinase activity through treatment of the cells with CX-4945, a highly selective inhibitor of CK2 kinase activity. It was shown earlier that sensitivity of cancer cell lines to CX-4945 can vary in a broad range [43]. Therefore, in early experiments we treated HCT116 cells with CX-4945 at different concentrations. Only about $65 \%$ of endogenous CK2 kinase activity of HCT116 cells was blocked after treatment with $1 \mu \mathrm{M}$ of CX-4945, while treatment of these cells with $10 \mu \mathrm{M}$ of CX-4945 lead to a nearly complete inhibition of endogenous CK2 kinase activity (Fig. 5b). We therefore decided to use this CK2 inhibitor at a concentration of $10 \mu \mathrm{M}$ for inhibition of endogenous CK2 kinase activity. As shown in Fig. 5 about $90 \%$ of endogenous CK2 kinase activity was inhibited after treatment of the HCT116 cells with CX-4945 for $24 \mathrm{~h}$ (Fig. 5b). Furthermore, promoter activities of both $C K 2 \alpha$ and $C K 2 \beta$ promoters were repressed in a dose-dependent manner when endogenous CK2 kinase activity was blocked by the selective CK2 inhibitor CX-4945 (Fig. 5a).

We further treated HCT116 cells with the structurally unrelated CK2 inhibitor TF [34]. At a concentration of $50 \mu \mathrm{M} \mathrm{TF}$, we found a decrease in endogenous CK2 kinase activity (Fig. 5e) comparable to the effect of treatment of the cells with $1 \mu \mathrm{M} \mathrm{CX}-4945$ (Fig. 5b). Analyses of $C K 2$ promoter activities (Fig. 5d) and endogenous $C K 2$ mRNA levels after treatment of the cells with TF (Fig. 5f), 

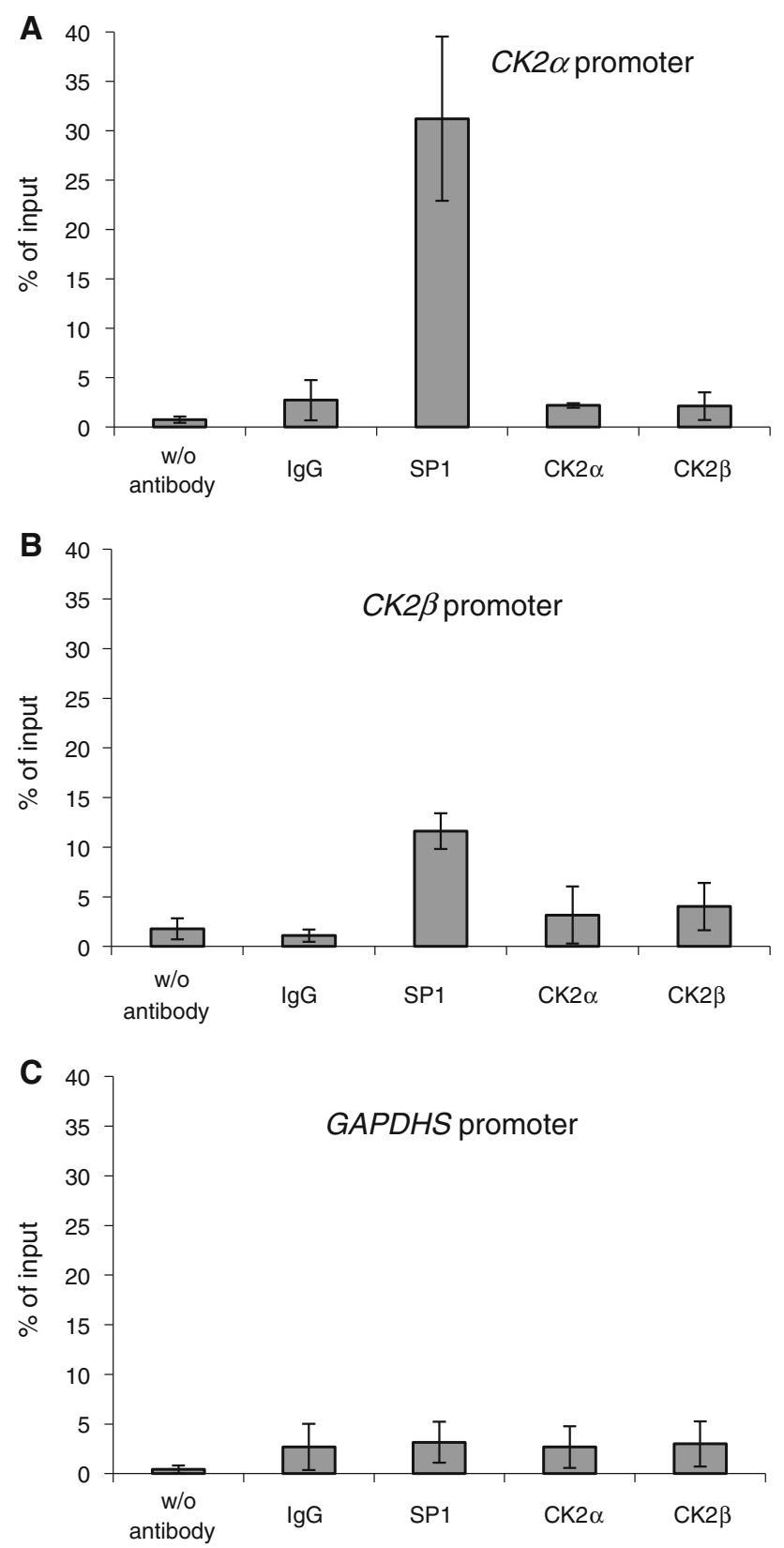

Fig. 4 Neither CK2 $\alpha$ nor CK2 $\beta$ subunits are able to bind in vivo to $C K 2 \alpha$ or $C K 2 \beta$ promoter regions. Nuclear extracts were prepared and chromatin immunoprecipitation analysis of CK2 subunit binding to the human $C K 2 \alpha$ (a) or $C K 2 \beta$ promoter (b) in vivo was performed with antibodies targeting CK $2 \alpha$ or CK2 $\beta$. Primer positions are shown in Fig. 1a, b. As negative controls, either no antibody (w/o antibody) or a non-targeting rabbit antibody (IgG) was used. Analysis of SP1binding served as a positive control. All signals are given relative to the input. c The GAPDHS promoter served as negative control for SP1 binding

revealed similar effects as they are induced by $1 \mu \mathrm{M}$ CX-4945 (Fig. 5a, c).

Taken together, our data suggest, that CK2 $\alpha$ and CK2 $\alpha^{\prime}$ influence the expression of $C K 2 \alpha$ and $C K 2 \beta$, on the transcriptional level not directly by binding to DNA but by the CK2 kinase activity.

\section{Discussion}

The regulation of protein kinase CK2 has been the subject of intensive research [44, 45]. Previous work mainly focused on regulation of CK2 kinase activity and protein level and led to the conviction, that CK2 is a ubiquitously expressed, constitutively active kinase [46, 47]. However, the CK2 kinase has also been shown to be a crucial constituent of tightly regulated cellular processes [48-50]. In addition, the expression and/or the activity of individual CK2 subunits seem to be controlled independently but very precisely. This is evidenced inter alia by differences in the relative expression of individual CK2 transcripts during embryonic development as well as by differential expression of $C K 2$ genes in diverse tissues of adult animals [48, $51,52]$. For example, CK2 $\alpha$ is widely expressed in all human tissues while CK $2 \alpha^{\prime}$ is predominantly expressed in testis and in brain $[10,53]$. Furthermore, the expression of CK2 $\beta$ protein differs from that of CK2 $\alpha$ and CK2 $\alpha^{\prime}$ proteins, suggesting variations in the composition of the tetrameric CK2 holoenzyme in different tissues [54]. The underlying mechanisms for such differences may comprise transcriptional and translational regulation, posttranslational modifications, and stabilization of CK2 subunits at both mRNA and protein level, as well as the subcellular localization of individual CK2 subunits or CK2 holoenzyme.

Little is known to date about the transcriptional regulation of CK2 subunit expression. In an early report, it was shown that CK2 bound to calf thymus DNA and to $\lambda$-phage DNA [40]. Blotting experiments showed that DNA bound CK2 through its $\alpha$-subunits. Pyerin et al. [29, 41, 42, 55] characterized DNA sequences upstream of the transcriptional start sites as promoter regions and used different fragments for promoter studies. Using gel mobility shiftassays as well as DNaseI footprinting, CK2 $\alpha$ was found to bind to fragments within these promoter sequences but only when CK2 $\alpha$ was expressed in excess of CK2 $\beta$ [29].

To address this issue, we decided to analyze transcriptional regulation of individual CK2 subunits with the focus on potential self-regulatory mechanisms. Previous studies suggested that relevant promoter regions of $C K 2 \alpha, C K 2 \beta$ genes are located within a few hundred base pairs upstream of the transcription start sites. In most of the experiments, even smaller DNA fragments were used for the analysis of transcriptional control $[18,56]$. Interestingly, the $C K 2 \alpha$ gene is organized with the first exon located over $35 \mathrm{~kb}$ upstream of the second exon, which harbors the start codon. Several eukaryotic genes are known with a first 

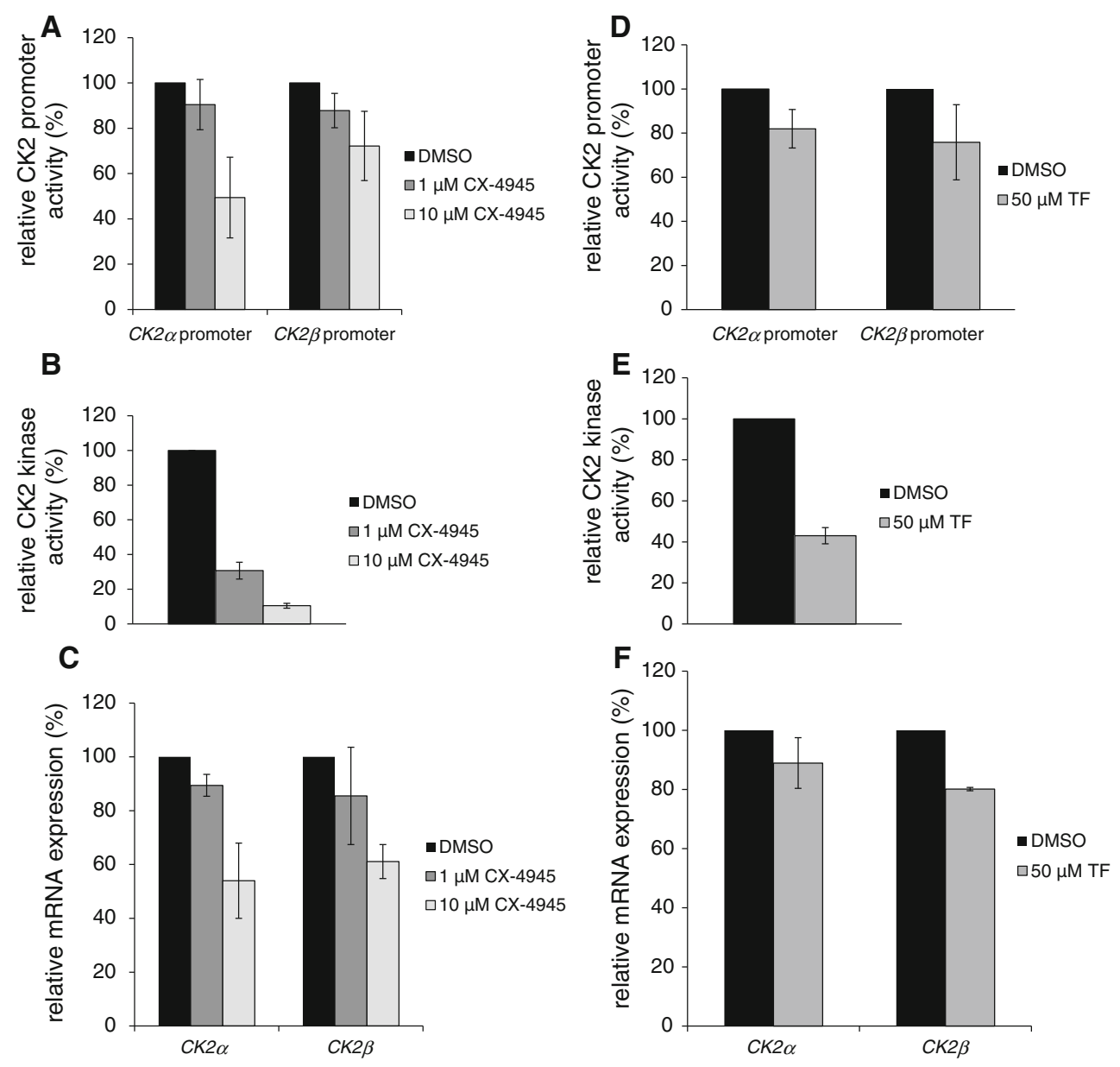

Fig. 5 CK2 promoter activities and endogenous mRNA levels decrease after inhibition of CK2 kinase activity with selective CK2 inhibitors CX-4945 (a-c) and TF (d-f). a, d Dual luciferase reporter gene assays were carried out in HCT116 cells after transient transfection of indicated $C K 2$ promoter constructs for $24 \mathrm{~h}$ and subsequent treatment with indicated concentrations of the CK2 inhibitors CX-4945 (a) or TF (d). Relative promoter activities, measured $24 \mathrm{~h}$ after treatment of the cells, are presented. CK2 promoter activities measured in DMSO-treated cells were set to

large intron, which harbor regulatory elements influencing gene expression [57-59]. Furthermore, it is described, that most regulatory elements are located in the $5^{\prime}$-flanking region of the ATG start codon of genes $[60,61]$. We therefore were wondered, if there were essential regulatory elements located directly upstream of the ATG start codon of human $C K 2 \alpha$ gene, which may contribute to expression control of CK2 $\alpha$ subunit. In order to gain further insights into the transcriptional regulation of the $C K 2 \alpha$ gene, we cloned a potential promoter region proximate to the $C K 2 \alpha$ start codon, encompassing over $1.3 \mathrm{~kb}$ (Fig. 1a, PI). We however found, that this proximal promoter region does not harbor any promoter activity (Fig. 1c). In contrast, analysis of a distal promoter construct, containing $1.9 \mathrm{~kb}$ upstream of the $C K 2 \alpha$ transcriptional start site (Fig. 1a, PII), reveals a very strong promoter activity (Fig. 1c). We therefore
$100 \%$. b, e Endogenous CK2 kinase activity in HCT116 cells was determined $24 \mathrm{~h}$ after treatment with DMSO (control) or indicated concentrations of CK2 inhibitors CX-4945 (b) or TF (e). Relative CK2 kinase activities measured in DMSO-treated control cells were set to $100 \%$. c, f Endogenous mRNA levels of $C K 2 \alpha$ and $C K 2 \beta$ were determined after treatment of HCT116 cells with indicated concentrations of CK2 inhibitors CX-4945 (c) or TF (f). mRNA levels in DMSO-treated control cells were set to $100 \%$

used this distal $C K 2 \alpha$ promoter construct for subsequent investigations of $C K 2 \alpha$ transcriptional regulation.

The organization of the $C K 2 \beta$ gene resemble that of $C K 2 \alpha$ concerning location of the start codon within exon 2 (Fig. 1b). The first untranslated exon however, is separated by a smaller intron, encompassing only $612 \mathrm{bp}$. In order to include all potential regulatory sequences, we cloned a DNA fragment of $1.9 \mathrm{~kb}$ upstream of the start codon of the $C K 2 \beta$ gene. This fragment includes complete sequences of intron 1 and untranslated exon 1 as well as the $5^{\prime}$-flanking region upstream of $C K 2 \beta$ transcriptional start site. Both, the $1.3 \mathrm{~kb}$ upstream sequence of the $C K 2 \alpha$ gene and the $1.9 \mathrm{~kb}$ upstream sequence of the $C K 2 \beta$ gene showed a dose-dependent promoter activity.

We found that the catalytic subunits of CK2 led to a moderate but significant trans-activation of both $C K 2 \alpha$ and 
$C K 2 \beta$ promoters, whereas the $\beta$-subunit did not show any significant transcriptional activation (Figs. 2, 3). According to our data from ChIP analyses, neither CK2 $\alpha$ nor CK2 $\beta$ bound to promoter sequences (Fig. 4) which seems to be different from the previous reports. However, Robitzki et al. [29] only observed binding of CK2 $\alpha$ to a promoter element when CK $2 \alpha$ was present in excess of CK2 $\beta$. In ChIP assays, we precipitated only endogenous CK2 subunits without any forced overexpression. Under these conditions CK2 $\alpha$ is complexed completely to CK2 $\beta$. Thus, we conclude from our results that CK2 $\alpha$ and CK2 $\beta$ do not function as transcription factors for their own expression. This conclusion was supported by the observation that inhibition of the kinase activity by two structurally unrelated inhibitors led to an attenuation of the transcriptional activation of the $C K 2 \alpha$ and $C K 2 \beta$ genes and to a decrease in CK2 mRNA levels (Fig. 5). Probably due to the wellknown high protein stability of CK2 subunits ([15, 62] and our own observation), we were not able to detect this effect on protein level (data not shown). Remarkable, inhibition of over $90 \%$ of endogenous CK2 kinase activity by CX-4945 (Fig. 5b) only leads to downregulation of promoter activities of about $50 \%(C K 2 \alpha)$ or $25 \%(C K 2 \beta)$, respectively (Fig. 5a). This discrepancy may be explained by basal control mechanisms of $C K 2$ promoter activities. $C K 2 \alpha$ as well as $C K 2 \beta$ promoters were basically influenced by several transcription factors, including SP1, ETS1, and NFKB [50, 51, 57]. Obviously, these transcription factors generate basal promoter activities of both promoters, while CK2 kinase activity itself seems to be responsible for the respective fine regulation and required for full promoter activities.

Therefore, our data suggest that CK2 regulates its transcription by phosphorylation of transcription factors. One of the candidates may be SP1 which was shown in this study to bind to both promoter elements and which was shown to be a substrate for CK2 [63, 64]. However, it was shown that phosphorylation of SP1 by CK2 led to a decrease in the DNA-binding activity of SP1 [63]. Thus, we conclude that SP1 is not the transcription factor which is activated by CK2 for the regulation of the CK2 gene expression. Ets1 is another transcription factor which is supposed to bind to the $C K 2 \alpha$ promoter [56]. So far, it is not known whether Ets1 is a substrate for CK2. However, there may be a number of other transcription factors implicated in the regulation of $C K 2$ gene expression which are not known so far. Work to identify these factors is currently in progress.

We have shown here that under normal physiological conditions $\mathrm{CK} 2$ does not bind to $C K 2$ promoter regions and that the CK2 kinase activity is implicated in the regulation of $C K 2 \alpha$ and $C K 2 \beta$ gene expressions.
Acknowledgments We thank David Litchfield, Thomas Kietzmann, Elitsa Dimova and Joachim José for the kind gifts of the expression plasmids of kinase-dead CK2 mutants, the probasin promoter reporter construct and the CK2 inhibitor TF, respectively. Furthermore we thank Claudia Götz for the subcloning of kinase-dead CK2 mutant constructs in p3xFLAG-CMV-7.1-basic vector and helpful suggestions and Nathaniel E. B. Saidu for carefully reading the manuscript.

\section{References}

1. Burnett G, Kennedy EP (1954) The enzymatic phosphorylation of proteins. J Biol Chem 211:969-980

2. Filhol O, Cochet C (2009) Protein kinase CK2 in health and disease: cellular functions of protein kinase CK2: a dynamic affair. Cell Mol Life Sci 66:1830-1839

3. St-Denis NA, Litchfield DW (2009) Protein kinase CK2 in health and disease: from birth to death: the role of protein kinase CK2 in the regulation of cell proliferation and survival. Cell Mol Life Sci 66:1817-1829

4. Trembley JH, Wang G, Unger G, Slaton J, Ahmed K (2009) Protein kinase CK2 in health and disease: CK2: a key player in cancer biology. Cell Mol Life Sci 66:1858-1867

5. Ahmad KA, Wang G, Slaton J, Unger G, Ahmed K (2005) Targeting CK2 for cancer therapy. Anticancer Drugs 16: 1037-1043

6. Pagano MA, Cesaro L, Meggio F, Pinna LA (2006) Protein kinase CK2: a newcomer in the 'druggable kinome'. Biochem Soc Trans 34:1303-1306

7. Thornburg W, Lindell TJ (1977) Purification of rat liver nuclear protein kinase NII. J Biol Chem 252:6660-6665

8. Dahmus ME, Natzle J (1977) Purification and characterization of Novikoff ascites tumor protein kinase. Biochemistry 16: 1901-1908

9. Stigare J, Buddelmeijer N, Pigon A, Egyhazi E (1993) A majority of casein kinase II alpha subunit is tightly bound to intranuclear components but not to the beta subunit. Mol Cell Biochem 129:77-85

10. Guerra B, Siemer S, Boldyreff B, Issinger OG (1999) Protein kinase CK2: evidence for a protein kinase CK2beta subunit fraction, devoid of the catalytic CK2alpha subunit, in mouse brain and testicles. FEBS Lett 462:353-357

11. Pinna LA, Meggio F (1997) Protein kinase CK2 ("casein kinase2 ") and its implication in cell division and proliferation. Prog Cell Cycle Res 3:77-97

12. Stalter G, Siemer S, Becht E, Ziegler M, Remberger K, Issinger OG (1994) Asymmetric expression of protein kinase CK2 subunits in human kidney tumors. Biochem Biophys Res Commun 202:141-147

13. Buchou T, Vernet M, Blond O, Jensen HH, Pointu H, Olsen BB, Cochet C, Issinger OG, Boldyreff B (2003) Disruption of the regulatory beta subunit of protein kinase CK2 in mice leads to a cell-autonomous defect and early embryonic lethality. Mol Cell Biol 23:908-915

14. Filhol O, Nueda A, Martel V, Gerber-Scokaert D, Benitez MJ, Souchier C, Saoudi Y, Cochet C (2003) Live-cell fluorescence imaging reveals the dynamics of protein kinase CK2 individual subunits. Mol Cell Biol 23:975-987

15. Lüscher B, Litchfield DW (1994) Biosynthesis of casein kinase II in lymphoid cell lines. Eur J Biochem 220:521-526

16. Wirkner U, Voss H, Lichter P, Weitz S, Ansorge W, Pyerin W (1992) Human casein kinase II subunit alpha: sequence of a processed (pseudo)gene and its localization on chromosome 11. Biochim Biophys Acta 1131:220-222 
17. Wirkner U, Voss H, Lichter P, Pyerin W (1994) Human protein kinase CK2 genes. Cell Mol Biol Res 40:489-499

18. Wirkner U, Voss H, Ansorge W, Pyerin W (1998) Genomic organization and promoter identification of the human protein kinase CK2 catalytic subunit alpha (CSNK2A1). Genomics 48:71-78

19. Wirkner U, Pyerin W (1999) CK2alpha loci in the human genome: structure and transcriptional activity. Mol Cell Biochem 191:59-64

20. Hung MS, Lin YC, Mao JH, Kim IJ, Xu Z, Yang CT, Jablons DM, You L (2010) Functional polymorphism of the CK2alpha intronless gene plays oncogenic roles in lung cancer. PLoS ONE 5:e11418

21. Yang-Feng TL, Naiman T, Kopatz I, Eli D, Dafni N, Canaani D (1994) Assignment of the human casein kinase II alpha' subunit gene (CSNK2A1) to chromosome 16p13.2-p13.3. Genomics 19:173

22. Boldyreff B, Issinger OG (1995) Structure of the gene encoding the murine protein kinase CK2 beta subunit. Genomics 29:253-256

23. Chen-Wu JL, Padmanabha R, Glover CV (1988) Isolation, sequencing, and disruption of the CKA1 gene encoding the alpha subunit of yeast casein kinase II. Mol Cell Biol 8:4981-4990

24. Hu E, Rubin CS (1991) Casein kinase II from Caenorhabditis elegans. Cloning, characterization, and developmental regulation of the gene encoding the beta subunit. J Biol Chem 266: 19796-19802

25. Ole-Moiyoi OK, Sugimoto C, Conrad PA, Macklin MD (1992) Cloning and characterization of the casein kinase II alpha subunit gene from the lymphocyte-transforming intracellular protozoan parasite Theileria parva. Biochemistry 31:6193-6202

26. Padmanabha R, Chen-Wu JL, Hanna DE, Glover CV (1990) Isolation, sequencing, and disruption of the yeast CKA2 gene: casein kinase II is essential for viability in Saccharomyces cerevisiae. Mol Cell Biol 10:4089-4099

27. Pons J, Evrard-Todeschi N, Bertho G, Gharbi-Benarous J, Benarous R, Girault JP (2007) Phosphorylation-dependent structure of ATF4 peptides derived from a human ATF4 protein, a member of the family of transcription factors. Peptides 28:2253-2267

28. Voss H, Wirkner U, Jakobi R, Hewitt NA, Schwager C, Zimmermann J, Ansorge W, Pyerin W (1991) Structure of the gene encoding human casein kinase II subunit beta. J Biol Chem 266:13706-13711

29. Robitzki A, Bodenbach L, Voss H, Pyerin W (1993) Human casein kinase II. The subunit alpha protein activates transcription of the subunit beta gene. J Biol Chem 268:5694-5702

30. Ryu SW, Woo JH, Kim YH, Lee YS, Park JW, Bae YS (2006) Downregulation of protein kinase CKII is associated with cellular senescence. FEBS Lett 580:988-994

31. Kim EK, Kang JY, Rho YH, Kim YS, Kim DS, Bae YS (2009) Silencing of the CKII alpha and CKII alpha' genes during cellular senescence is mediated by DNA methylation. Gene 431:55-60

32. Brattain MG, Fine WD, Khaled FM, Thompson J, Brattain DE (1981) Heterogeneity of malignant cells from a human colonic carcinoma. Cancer Res 41:1751-1756

33. Bunz F, Dutriaux A, Lengauer C, Waldman T, Zhou S, Brown JP, Sedivy JM, Kinzler KW, Vogelstein B (1998) Requirement for p53 and p21 to sustain G2 arrest after DNA damage. Science 282:1497-1501

34. Götz C, Gratz A, Kucklaender U, Jose J (2012) TF: a novel cellpermeable and selective inhibitor of human protein kinase CK2 induces apoptosis in the prostate cancer cell line LNCaP. Biochim Biophys Acta 1820:970-977

35. Penner CG, Wang Z, Litchfield DW (1997) Expression and localization of epitope-tagged protein kinase CK2. J Cell Biochem 64:525-537
36. Schneider CC, Gotz C, Hessenauer A, Gunther J, Kartarius S, Montenarh M (2011) Down-regulation of CK2 activity results in a decrease in the level of cdc25C phosphatase in different prostate cancer cell lines. Mol Cell Biochem 356:177-184

37. Rother K, Li YY, Tschöp K, Kirschner R, Müller GA, Mössner J, Engeland K (2007) Expression of cyclin-dependent kinase subunit 1 (Cks1) is regulated during the cell cycle by a CDE/CHR tandem element and is downregulated by p 53 but not by p 63 or p73. Cell Cycle 6:853-862

38. Faust M, Schuster N, Montenarh M (1999) Specific binding of protein kinase CK2 catalytic subunits to tubulin. FEBS Lett 462:51-56

39. Mannefeld M, Klassen E, Gaubatz S (2009) B-MYB is required for recovery from the DNA damage-induced G2 checkpoint in p53 mutant cells. Cancer Res 69:4073-4080

40. Filhol O, Cochet C, Chambaz EM (1990) DNA binding activity of casein kinase II. Biochem Biophys Res Commun 173:862-871

41. Krehan A, Ansuini H, Bocher O, Grein S, Wirkner U, Pyerin W (2000) Transcription factors ets1, NF-kappa B, and Sp1 are major determinants of the promoter activity of the human protein kinase CK2alpha gene. J Biol Chem 275:18327-18336

42. Pyerin W, Ackermann K (2001) Transcriptional coordination of the genes encoding catalytic (CK2alpha) and regulatory (CK2beta) subunits of human protein kinase CK2. Mol Cell Biochem 227:45-57

43. Siddiqui-Jain A, Drygin D, Streiner N, Chua P, Pierre F, O'Brien SE, Bliesath J, Omori M, Huser N, Ho C, Proffitt C, Schwaebe MK, Ryckman DM, Rice WG, Anderes K (2010) CX-4945, an orally bioavailable selective inhibitor of protein kinase CK2, inhibits prosurvival and angiogenic signaling and exhibits antitumor efficacy. Cancer Res 70:10288-10298

44. Allende CC, Allende JE (1998) Promiscuous subunit interactions: a possible mechanism for the regulation of protein kinase CK2. J Cell Biochem Suppl 30-31:129-136

45. Montenarh M (2010) Cellular regulators of protein kinase CK2. Cell Tissue Res 342:139-146

46. Litchfield DW (2003) Protein kinase CK2: structure, regulation and role in cellular decisions of life and death. Biochem $\mathrm{J}$ 369:1-15

47. Turowec JP, Duncan JS, French AC, Gyenis L, St Denis NA, Vilk G, Litchfield DW (2010) Protein kinase CK2 is a constitutively active enzyme that promotes cell survival: strategies to identify CK2 substrates and manipulate its activity in mammalian cells. Methods Enzymol 484:471-493

48. Alvarez LM, Revuelta-Cervantes J, Dominguez I (2013) CK2 in embryonic develpoment. In: Pinna LA (ed) Protein kinase CK2. Wiley, Oxford, pp 129-168

49. Gabriel M, Litchfield DW (2013) Protein Kinase CK2: at the crossroads of pathways controlling cell proliferation and survival. In: Pinna LA (ed) Protein kinase CK2. Wiley, Oxford, pp 169-189

50. Trembley JH, Wu J, Unger GM, Kren BT, Ahmed K (2013) CK2 suppression of apoptosis and its implication in cancer biology and therapy. In: Pinna LA (ed) Protein kinase CK2. Wiley, Oxford, pp 319-343

51. Dominguez I, Degano IR, Chea K, Cha J, Toselli P, Seldin DC (2011) CK2alpha is essential for embryonic morphogenesis. Mol Cell Biochem 356:209-216

52. Landesman-Bollag E, Belkina A, Hovey B, Connors E, Cox C, Seldin DC (2011) Developmental and growth defects in mice with combined deficiency of CK2 catalytic genes. Mol Cell Biochem 356:227-231

53. Xu X, Toselli PA, Russell LD, Seldin DC (1999) Globozoospermia in mice lacking the casein kinase II alpha' catalytic subunit. Nat Genet 23:118-121 
54. Maridor G, Park W, Krek W, Nigg EA (1991) Casein kinase II. cDNA sequences, developmental expression, and tissue distribution of mRNAs for alpha, alpha', and beta subunits of the chicken enzyme. J Biol Chem 266:2362-2368

55. Ackermann K, Neidhart T, Gerber J, Waxmann A, Pyerin W (2005) The catalytic subunit alpha' gene of human protein kinase CK2 (CSNK2A2): genomic organization, promoter identification and determination of Ets 1 as a key regulator. Mol Cell Biochem 274:91-101

56. Krehan A, Schmalzbauer R, Bocher O, Ackermann K, Wirkner U, Brouwers S, Pyerin W (2001) Ets1 is a common element in directing transcription of the alpha and beta genes of human protein kinase CK2. Eur J Biochem 268:3243-3252

57. Bornstein P, McKay J, Morishima JK, Devarayalu S, Gelinas RE (1987) Regulatory elements in the first intron contribute to transcriptional control of the human alpha 1(I) collagen gene. Proc Natl Acad Sci USA 84:8869-8873

58. Coulon V, Chebli K, Cavelier P, Blanchard JM (2010) A novel mouse c-fos intronic promoter that responds to CREB and AP-1 is developmentally regulated in vivo. PLoS ONE 5:e11235

59. Majewski J, Ott J (2002) Distribution and characterization of regulatory elements in the human genome. Genome Res 12: $1827-1836$
60. Lantinga-van Leeuwen IS, Leonhard WN, Dauwerse H, Baelde HJ, van Oost BA, Breuning MH, Peters DJ (2005) Common regulatory elements in the polycystic kidney disease 1 and 2 promoter regions. Eur J Hum Genet 13:649-659

61. Stauffer DR, Chukwumezie BN, Wilberding JA, Rosen ED, Castellino FJ (1998) Characterization of transcriptional regulatory elements in the promoter region of the murine blood coagulation factor VII gene. J Biol Chem 273:2277-2287

62. Seeber S, Issinger OG, Holm T, Kristensen LP, Guerra B (2005) Validation of protein kinase CK2 as oncological target. Apoptosis 10:875-885

63. Armstrong SA, Barry DA, Leggett RW, Mueller CR (1997) Casein kinase II-mediated phosphorylation of the $\mathrm{C}$ terminus of Sp1 decreases its DNA binding activity. J Biol Chem 272: 13489-13495

64. Harris SM, Harvey EJ, Hughes TR, Ramji DP (2008) The interferon-gamma-mediated inhibition of lipoprotein lipase gene transcription in macrophages involves casein kinase 2- and phosphoinositide-3-kinase-mediated regulation of transcription factors Sp1 and Sp3. Cell Signal 20:2296-2301 